Acta vet. scand. 1967, 8, 193-194.

Brief Communication

\title{
VARIATION OF HORSE PREALBUMINS IN ACIDIC STARCH GELS
}

Working with acidic starch gels (pH 5.9) Brænd \& Efremov (1965) detected a large number of horse serum protein zones migrating faster than the albumins. In the present communication these proteins shall be called acidic prealbumins or just prealbumins.

The technique employed is based upon Poulik's (1957) discontinuous system. The material comprised serum and plasma samples from 30 horses representing a variety of breeds which were tested monthly over half a year. In addition three horse families consisting of 30,9 and 5 dam-offspring pairs respectively were investigated.

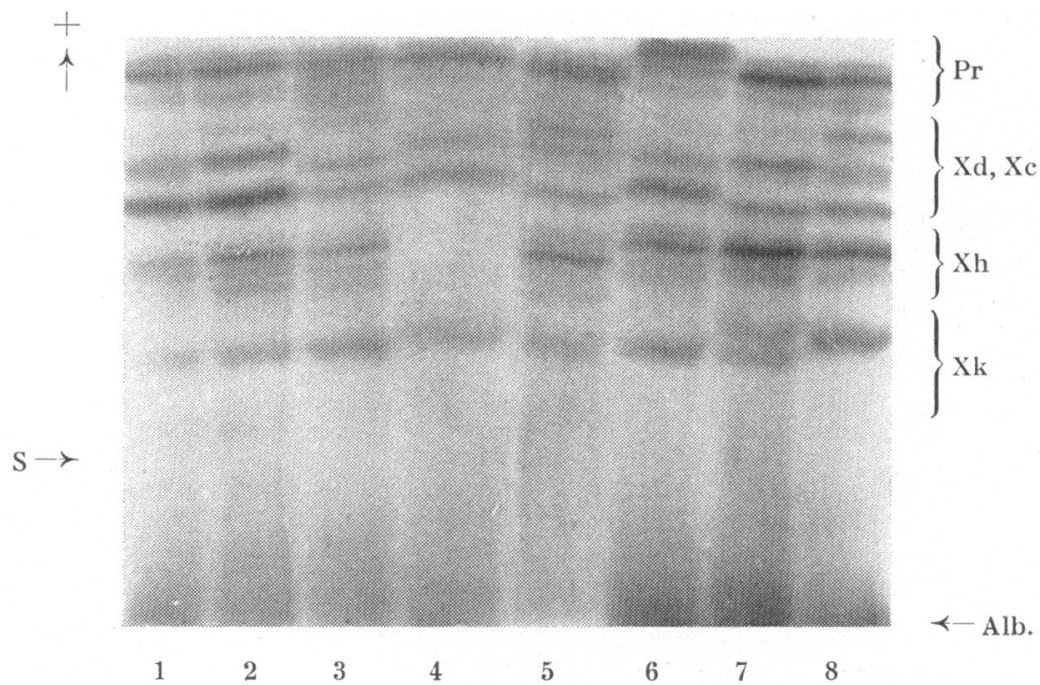

Fig u re 1. Prealbumins of 8 horses, gel buffer $\mathrm{pH} 5.0$.

The appearance of acidic prealbumins is shown in Fig. 1. The fastest migrating are those studied by Gahne (1966) by him called the $\mathrm{Pr}$ system. Studies in our laboratory indicate that these proteins correspond to $\alpha_{1}$-antitrypsin.

The rest of the prealbumins are assumed to represent a variety of protein systems. They have been given tentative names $\mathrm{Xk}, \mathrm{Xh}$, 
etc. where $\mathrm{X}$ stands for the unknown and the second letter for the order of migration. The slowest one is the Xk system where four different phenotypes were diagnozed. Most common is the KK phenotype which appears as one band only. Most of the samples in Fig. 1 are KK. A faster phenotype, FF, is seen in sample no. 8 and a two band, FK, type in no. 7. Another two band phenotype, KS, is seen in nos. 1 and 2. The position of the $S$ band, which is rather faint on the photograph is marked with an arrow. These results suggested a genetic theory of three codominant alleles, $\mathrm{Xk}^{\mathrm{F}}, \mathrm{Xk}^{\mathrm{K}}$ and $\mathrm{Xk}^{\mathrm{S}}$. Family studies agree with the theory.

In front of the Xk proteins another group of protein zones can be seen. These are assumed to represent another system, Xh. Most of the samples in Fig. 1 show the same Xh phenotype designated HH. A different phenotype, LL, is shown in no. 5 . A combination between these two has been found as well as other phenotypes.

Between the $\mathrm{Pr}$ and $\mathrm{Xh}$ systems a rather great number of different protein bands have been found. The studies undertaken so far suggest two variable and partly overlapping systems tentatively called Xd and Xc.

\section{Brænd}

Department of Medicine,

Veterinary College of Norway, Oslo.

\section{REFERENCES}

Brænd, M. \& G. Efremov: Haemoglobins, haptoglobins and albumins of horses. Proc. 9th Europ. Animal Blood Group Conf. 1965, 253259.

Gahne, B.: Studies on the inheritance of electrophoretic forms of transferrins, albumins, prealbumins and plasma esterases of horses. Genetics 1966, 53, 681-694.

Poulik, M. D.: Starch gel electrophoresis in a discontinuous system of buffers. Nature (Lond.) 1957, 180, 1477-1478. 

